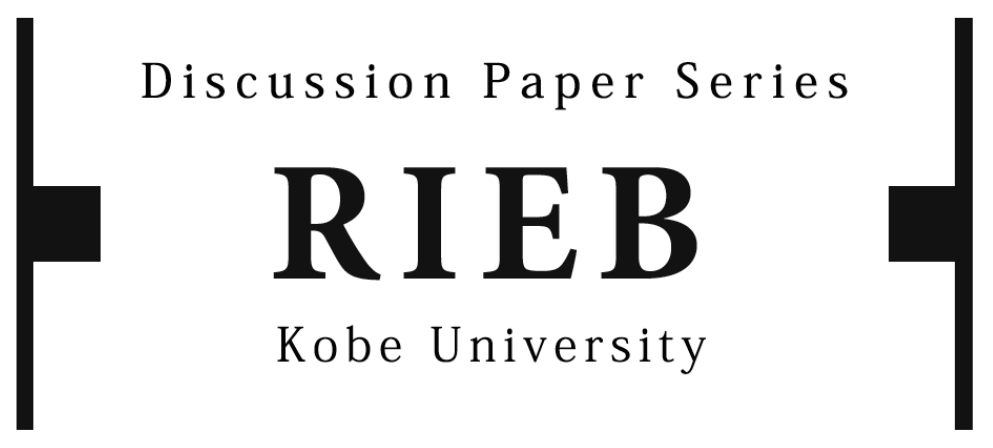

DP2014-07

\title{
Greasing the Wheels? \\ The Effect of Corruption in Regulated Manufacturing Sectors of India*
}

\author{
Atsushi KATO \\ Takahiro SATO
}

March 4, 2014

* The Discussion Papers are a series of research papers in their draft form, circulated to encourage discussion and comment. Citation and use of such a paper should take account of its provisional character. In some cases, a written consent of the author may be required.

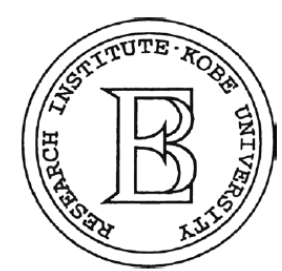

Research Institute for Economics and Business Administration Kobe University 


\section{Greasing the wheels?}

The effect of corruption in regulated manufacturing sectors of India

Corresponding author:

Atsushi Kato

School of Business, Aoyama Gakuin University,

4-4-25 Shibuya, Shibuya-ku, Tokyo, 150-8366, Japan

TEL (81)-3-3409-8111, FAX (81)-3-3797-6870

Email: kato@busi.aoyama.ac.jp

Co-author:

Takahiro Sato

Research Institute for Economics \& Business Administration

Kobe University

2-1, Rokkodai-cho, Nada-ku, Kobe, Hyogo, 657-8501 Japan 


\title{
Greasing the Wheels? The Effect of Corruption in Regulated Manufacturing Sectors of India
}

\begin{abstract}
We investigate whether corruption "greases the wheels" of bureaucracies and enhances economic performance. Specifically, we examine the interaction effect of corruption and regulation on the economic performance of manufacturing industries in India. Our estimation results show that the combination of corruption and regulation has significant positive effects on gross value added per worker, total factor productivity, and capital labor ratio. This indicates the existence of a "greasing the wheels" effect.
\end{abstract}

Keywords: corruption, regulation, gross value added per worker, TFP

JEL Classification No.: D73, K42, L52, K23.

\section{Introduction}

There has long been controversy over the effects of corruption, most notably between the "grease the wheels" hypothesis and the "sand the wheels" hypothesis (e.g., Meon and Sekkat 2005). Some scholars (e.g., Huntington 1968, Leys 1970, Lui 1985) have claimed that corruption "greases the wheels” of dysfunctional bureaucracies, and thereby enhances economic performance. However, since the mid-1990s a large body of empirical literature has presented evidence that corruption has unfavorable effects on economic performance measures such as investment, GDP growth rates, GDP per capita, and productivity (e.g., Mauro 1995, Hall and Jones 1999, Wyatt 2002, Brunetti et al. 1998, Campos et al. 1999, Gyimah-Brempong 2002). These studies lend support to the "sand the wheels" hypothesis. ${ }^{1}$ It appeared that a consensus was emerging among academics concerning the negative effects of corruption. Recently, however, a few influential empirical studies have reported some 
positive effects of corruption in countries with lower institutional quality or weaker governance.

Klapper et al. (2006) have shown that barriers to entry are more effective in low-corruption countries than in high-corruption countries, where corruption offsets the negative effects of entry regulation. Dreher and Gassebner (2013) have reported that, in highly regulated economies, corruption significantly increases entrepreneurial activity. While these studies concerned the entry of firms, Meon and Weill (2010) have shown that corruption has a positive effect on efficiency when the quality of governance is very low but a negative effect when the quality of governance is high. These studies emphasize that the negative effects of corruption are largely consistent with its positive effect in inferior institutional frameworks. However, several recent studies dispute the positive effects of corruption in an inferior institutional framework. Among others, Meon and Sekkat (2005) show that the negative effect of corruption on growth rate and investment is more severe in countries with lower quality of governance. ${ }^{2}$ These studies have reignited the old debate about the effects of corruption.

Our study complements previous research by focusing on the economic performance of domestic manufacturing industries, comparing performance among Indian regional states, which vary in the extent of corruption. More concretely, we examine whether corruption has positive effects on the productivity of regulated manufacturing industries by looking at the coefficient of the interaction term of corruption and regulation on the economic performance of Indian manufacturing industries 
at the three-digit level. We capture the extent of corruption by using data on the incidence of corruption-related cases in each Indian state, while addressing the problems of underreporting in official data and endogeneity in the relationship between economic performance and corruption. Our estimation results show that the combination of corruption and regulation actually has significant positive effects on gross value added per worker and its decomposed factors, total factor productivity (TFP) and capital labor ratio, thus supporting the "grease the wheels" hypothesis.

Regulation, at least beyond a certain level, is widely considered by economists to hinder economic performance. Excessive regulation distracts corporate managers and keeps them from value-creating business activities. It also discourages entrepreneurs from entering new markets. Moreover, the realization of new business ideas may be hampered by stringent regulations. Many empirical studies have shown that various kinds of regulation produce deleterious effects on market entry (Desai et al. 2003, Scarpetta et al. 2002), investment (Alesina et al. 2005), economic growth (Djankov et al. 2006, Loayza et al. 2005a, b), output per worker (Barseghyan 2008), total factor productivity (Barseghyan 2008, Nicoletti and Scarpetta 2003), macroeconomic volatility (Loayza et al. 2005b), research and development intensity (Bassanimi and Ernst 2002), and social capital (Aghion et al. 2010).

During the license-raj era, India was notorious for its stringent bureaucratic control of industries. Bhagwati (1993) described the control of industry by the government during this time as follows. 
The Indian planners and bureaucrats sought to regulate both domestic entry and import competition, to eliminate product diversification beyond what was licensed, to penalize unauthorized expansion of capacity, to allocate and prevent the reallocation of imported inputs, and indeed to define and delineate virtually all aspects of investment and production through a maze of Kafkaesque controls. This all-encompassing bureaucratic intrusiveness and omnipotence has no rationale in economic or social logic; it is hard for anyone who is not a victim of it even to begin to understand what it means.

Even after the sequence of delicensing starting in the 1980s, widespread inefficiency in the Indian government persists. For instance, the Doing Business project, conducted by the World Bank, ranks countries in 10 categories related to business environment. Out of the 178 countries in Doing Business 2008, India ranks 111th on the "starting a business" indicator and 134th on the "dealing with licenses” indicator (World Bank 2008).

Nevertheless, burdensome regulations may be circumvented if public officials speed up procedural processes or overlook regulatory noncompliance. Such favors are often given in exchange for bribes. In this case, corruption allows businesses to detour around cumbersome regulatory procedures and engage in value-creating business activities. In the rest of the paper, we refer to this as the "greasing the wheels" effect. Here, we examine whether this effect operates at the 
three-digit level in the manufacturing sectors under regulation in India.

Conditions in India since the deregulation of the mid-1980s, which included large-scale industry delicensing, provide ideal environment for our research. Many scholars argue that corrupt public officials tend to distort regulations so that they will have more opportunities for bribe-taking (e.g., Kauffman 1997). If this argument is valid, the extent of regulation is linked to the extent of corruption, and it will therefore be difficult to examine their separate effects on economic performance. However, the deregulation process of the mid-1980s to early 1990s was driven by factors usually considered to be independent of corruption. The Government of India began to delicense some manufacturing industries since the mid-1980s and accelerated the process in the early 1990s. The delicensing process peaked twice, in 1985 and 1991 (Aghion et al. 2008). The first delicensing peak, mainly in the electrical and electronics sector, was promoted by Prime Minister Rajiv Gandhi because of his desire to promote the sector. This delicensing was successfully implemented due to his charisma and clean reputation. In 1991, the Government of India pushed through even more drastic delicensing of manufacturing sectors. At that time delicensing was inevitable given the external pressure from the IMF and the World Bank. Economic liberalization packages were prepared by a small team of economic technocrats, including Motek Singh Alhwalia, Rakesh Mohan, and Rajiv Kumar, who were referred to as the “change team” (see Shastri (1997) for the roles played by the change team in the economic liberalization in 1991). Furthermore, in order to 
avoid opposition in the Parliament, "critical reforms in industrial policy in 1991 were made as executive decisions” (Kohli 2006, p.1363). In this way deregulation of manufacturing industries was forced through by exogenous factors in India and implemented without opportunity for counter-attacks by those entangled within the networks of corruption. ${ }^{3}$

India is notorious as much for its corruption as for its strict regulation (Wade 1985, Transparency International 2002, Transparency International India 2005, 2008, Bertrand et al. 2007). Among six World Governance Indicators compiled by Kaufmann, et al. (2008), India's position with respect to "control of corruption" on a standard normal distribution is -0.39 , below the mean zero, which indicates that India has widespread corruption. There is little doubt that corporate actors in India are affected by corruption, and it is therefore meaningful to study the effects of corruption on economic performance in India.

In the field of comparative politics, more attention has recently been paid to regional differences within a country. Jenkins (2004) asserts the value of comparative political analysis of Indian states. India’s federal system has created 29 'mini-democracies’ with almost identical institutional infrastructures, at least in terms of the formal systems of representation. India's States, moreover, operate under a set of common conditions, including New Delhi's foreign and economic policy framework and the legal protections enshrined in the Indian Constitution. These control variables represent a major boon to students of 
comparative politics who seek to understand and explain the divergent patterns and outcomes that the practice

of democracy can produce.

For instance, in the context of our study the definition of corruption may not be uniform across different countries, cultures, laws, and business practices (Philip 1997, Gardiner 2002). We can expect that the interpretation of the meaning of "corruption" is less variable across the regions of one country than across countries. Thus, it is meaningful to conduct interstate comparative analysis with respect to the effects of corruption.

Comparative political analyses on Indian states have shown that various political factors, including ideology, the support bases and organizational structures of political parties, and the types of bureaucracies, influence the choice, implementation, and outcomes of state policies. For example, Harriss (2003) shows that the political regime in each Indian state determines the adoption and extent of antipoverty policy. Kennedy et al. (2013) argue that since the early 1990s, different types of political compromises between social groups have determined the variation in the responses of state governments to economic reforms at the national level. Chhibber and Nooruddin (2004) provide evidence that party systems affect the allocation of government expenditures. Furthermore, Sinha (2005) states that the competence and attitudes of bureaucrats are important determinants of the state's effectiveness in attracting investments. Our study accords with Sinha's view in the sense that 
we examine whether corrupt practices of bureaucrats affect economic outcomes.

In addition, when comparing regional states within one country, the effects of corruption on the corporate sector should be more easily observed than in cross-national studies, which usually relate the extent of corruption at the national level to national economic performance. If there are large differences between the corruption levels of states within a country, entrepreneurs could avoid corrupt regions and locate themselves instead in less corrupt regions. Large variations among Indian states in business climate, including corruption, have been reported. Iarrosi (2009) used the data collected through the Firm Analysis and Competitiveness Survey (FACS) conducted by the World Bank to construct the Investment Climate Index (ICI) of 16 major Indian states. The extent of corruption is taken into account in the construction of the ICI. Iarrosi found that the ICI explains well the variation in private domestic investments and the growth rates of gross state domestic products, and that there is wide variation in the ICI across Indian states from Karnataka and Kerala at the top of the index to Rajasthan and Uttar Pradesh at the bottom. ${ }^{4}$ We will examine the effect of one important element of business environment, corruption, on economic performance of the manufacturing sector across the Indian states.

In addition to the importance of the research agenda taken up in this study in terms of policy implications, we make two methodological contributions in this study; first, the use of the conviction rate in corruption-related cases as an instrumental variable for the extent of corruption; second, the 
use of official data on corruption while addressing the problem of underreporting.

First, we explain the usefulness of the conviction rate as an instrumental variable. The literature on the effect of corruption on economic performance has consistently shown that corruption lowers investment rates. Some scholars have shown that economic growth rates are adversely affected by corruption, although these studies have been less conclusive. Only a few studies, however, have investigated the relationship between corruption and GDP per capita (Hall and Jones 1999, Kaufmann et al. 1999). GDP per capita, or output per worker, is closely related to the material well-being of the people and to social indicators such as life expectancy and infant mortality (Ray 1998). It is therefore worthwhile to investigate the effects of corruption on such productivity measures. These productivity measures, however, could also influence the level of corruption of a country, and the endogeneity problem should be addressed by a method such as instrumental variable estimation. Hall and Jones (1999) and Kaufmann et al. (1999) both use the fraction of the population speaking English and the fraction of the population speaking a major European language (English, French, German, Portuguese, or Spanish) as instrumental variables. However, some scholars have cast doubt on the validity of these instrumental variables (Lamsdorff 2006). Instrumental variables must be correlated with the extent of corruption, but not with GDP per capita, and the fraction of the population speaking a major European language may affect GDP per capita through factors other than corruption, such as political instability, inequality, unsecure property 
rights, human capital, and social capital. Because of the difficulty of obtaining appropriate instruments, studies of the impact of corruption on productivity measures such as GDP per capita or gross value added per worker are relatively rare.

This study focuses on gross value added per worker and its decomposed factors (total factor productivity and capital-labor ratio) as our dependent variables, employing the conviction rates in corruption-related cases as an instrument for the extent of corruption. To our best knowledge, conviction rates have not previously been used as an instrument for corruption. The conviction rate in corruption-related cases may influence the level of corruption by affecting the expected returns from corruption for public officials, but conviction rates do not seem to affect the performance of three-digit level manufacturing industries through factors other than corruption. ${ }^{5}$

The second advantage of our study is its use of official corruption data while addressing the problem of underreporting. Several studies have recently criticized perception-based corruption indices, which have been widely used in previous studies, as seriously biased (Mocan 2004, Abramo 2005, Andvig 2005, Svennson 2005, Razafindrakoto and Routboud 2006). For example, critics say that respondents evaluate the extent of corruption based on their own past experiences, and hence their assessment changes slowly and does not reflect the present extent of corruption. Olken (2009) shows that a gap exists between the perception of corruption and the actual extent of corruption in Indonesian villages. The assessments may also suffer from subjectivity problems 
because of differences in respondents' personal characteristics or backgrounds. Moreover, it has been shown that vulnerability to corruption differs between industries, and that the extent of corruption differs between regions in a country. Therefore, evaluations by individuals who have knowledge limited to specific industries and regions may be biased with respect to the extent of corruption for the whole country.

To complement previous cross-country studies, which used a perception-based corruption index, we will measure the extent of corruption by the official number of cases related to violations of anti-corruption laws. The use of data on such corruption-related cases has some advantages. First, the number does not depend on subjective individual assessments. Second, we can obtain reasonable instrumental variables (conviction rate in our study) for the number of corruption-related crime cases. Third, by using this variable, we can more easily conduct panel data estimation than was possible in the previous cross-country studies using a perception-based corruption index. For instance, because of the differing availability of data across years and countries, the corruption-monitoring organization Transparency International utilizes several different sources to construct the Corruption Perceptions Index (CPI). The CPI for India from 2004 is based on data from 15 separate surveys; the CPI from 2010 is based on only 10. Thus, it is difficult to justify the use of time-series analysis on CPI data. For this reason, many previous studies using the CPI have conducted cross-national analyses. However, cross-national studies can produce biased results because they do not properly 
control for unobserved time-invariant country characteristics, which can be controlled for in panel data analysis. In this regard, data on the incidence of corruption-related cases provide a useful measure of corruption severity, allowing for the capture of the time-series effects of corruption.

An obvious and serious disadvantage of such official corruption data is inaccuracy in the reporting of crimes. This is the main reason that official corruption data has rarely been used in the literature. Criminologist Marenin (1997) expresses concern about the reliability of cross-country comparisons of crime data because the reliability of reporting and recordkeeping varies among countries. The International Crime Victimization Surveys (1996/97) show differences in the propensity to report corruption among some developing countries. Table 33 in this publication (p. 92) shows that in Paraguay the rate of reporting is 8.9 per cent but in Argentina it is only 0.7 per cent. Indian corruption reporting is greater than the median with a reporting rate of 6.3 per cent. We address the underreporting problem by employing a method similar to that proposed by Soares (2004). Soares uses the International Crime Victimization Surveys (ICVS) and presents a regression of the reporting rates of various crimes on several relevant variables. He then applies the estimation results to official crime data to obtain predicted true crime rates. We adopt a similar approach to address the problem of underreporting in the official data on corruption. ${ }^{6}$

The rest of the article is organized as follows. The next section explains our empirical methodology, data and variable construction, and the method used to address the problem of 
underreporting. Our estimation results are presented in the following section, and the final section concludes the article.

\section{Empirical Formulation}

\section{Empirical methodology}

In this article, we estimate the following equation:

$$
Y_{i s t}=\alpha+\beta_{1} \text { reg }_{i t}+\beta_{2} \text { corruption }_{s t}+\beta_{3} \text { reg }_{i t} \times \text { corruption }_{s t}+\theta_{t}+\theta_{i}+\theta_{s}+t+\varepsilon_{i s t},
$$

where $Y_{\text {ist }}$ is a variable representing the economic performance of three-digit manufacturing sector $i$ of state $s$ in year $t$. In our estimation equation above, $\theta_{t}$ is a year dummy, $\theta_{i}$ is a dummy variable for each three-digit industry $\mathrm{i}$, and $\theta_{s}$ is a dummy variable for state $s$. The variable $t$ captures common time trends.

The variable corruption st $_{\text {is }}$ the predicted true incidence of corruption averaged over the current and previous year. Details of the construction of the variable corruption are explained in the subsection on underreporting problem and construction of a corruption variable. The dummy variable reg $_{i t}$ is set to one if the three-digit manufacturing sector $i$ is regulated in year $t$ and zero otherwise. The information on the timing of deregulation in each three-digit manufacturing industry 
is available in the data appendix of Aghion et al. (2008) on the American Economic Review website.

Our main focus is the combined effect of corruption and regulation on gross value added per worker, namely, the coefficient of the interaction term reg*corruption. It is known that a Cobb-Douglass gross value added production function with constant returns to scale,

$$
Y=A K^{\alpha} L^{1-\alpha},
$$

can be transformed under certain conditions into

$$
\ln \frac{Y}{L}=\ln A+\alpha \ln \frac{K}{L},
$$

where $Y$ is value added, $K$ is capital, $L$ is labor, and $A$ is total factor productivity. Thus, we also examine the effects on these two dependent variables.

We use instrumental variable estimation to address the endogeneity problem with regard to corruption and economic performance. On the one hand, as more economic activities are conducted, more opportunities for corruption arise. On the other hand, as the economy of a state develops, the state government can provide more resources to combat corruption. To address the endogeneity problem, we use the conviction rate (denoted by conviction) as an instrumental variable for 
corruption. The variable conviction is constructed as the ratio of the number of convictions in corruption-related cases to the number of corruption-related cases under investigation in that year. If this number is high, public servants may refrain from engaging in corrupt behavior because they perceive the probability of being caught and punished to be high. We conduct a two-stage least square estimation using this instrumental variable.

Another endogeneity problem may arise between regulation and economic performance of manufacturing industries. In general, an industry that had inferior performance is more likely to request government protection (sometimes by bribing public officials), which causes an endogeneity problem between economic performance and regulation. As mentioned in the introduction, the problem of endogeneity between regulation and the performance of manufacturing industries is not serious during our sample period because, as already mentioned, the deregulation processes of the 1980s and early 1990s were driven primarily by exogenous factors.

\section{Data and variable construction}

We use data on states and three-digit manufacturing sectors based on the 1987 National Industrial

Classification (NIC1987) as our sample. Because corruption data are quite limited in other states, we focus on 17 major states. Our main data source is the Annual Surveys of Industries, compiled by the Central Statistics Office of the Government of India. Our sample period runs from 1988 to 1997. 
Because of changes in the compilation policy of the Central Statistics Office, it is difficult to consistently extend the data on three-digit manufacturing sectors beyond 1997. Many manufacturing industries were deregulated during the sample period. ${ }^{7}$

The dependent variables are constructed as follows. First, we obtain real gross value added by dividing the gross value added of each three-digit manufacturing industry in each year and state, available in Annual Survey of Industries, by the deflator for the value of gross output at the two-digit industry level. We then divide the real gross value added by the number of workers in the three-digit manufacturing industry to obtain gross value added per worker.

Capital stock is obtained by dividing fixed capital from Annual Survey of Industries by the implicit capital deflator used in National Accounts Statistics, published by Central Statistical Office, the Ministry of Statistics and Programme Implementation of India. We then divide the capital stock by the number of workers in the three-digit manufacturing sector.

To obtain TFP, we use the Levinsohn-Petrin method (Levinsohn and Petrin 2003) to estimate the value added production function with log real value added as a dependent variable and log real capital stock and log number of workers as independent variables, using deflated total inputs as a proxy variable. To obtain log TFP, we then insert the estimated coefficients back into the production function and subtract the coefficients multiplied by the values of the independent variables from log real value added. 
Table 1: Summary Statistics

\begin{tabular}{|c|c|c|c|c|c|}
\hline Variable & $\begin{array}{c}\text { No. of } \\
\text { observations }\end{array}$ & Mean & S.D. & Min & Max \\
\hline gross value added per worker & 18874 & 0.651 & 1.802 & -35.194 & 127.428 \\
\hline capital-labor ratio & 18870 & 255.44 & 682.28 & 0.05 & 43208.59 \\
\hline total factor productivity & 18434 & 1.932 & 2.481 & 0.0004 & 119.5270 \\
\hline reg & 35343 & 0.325 & 0.469 & 0 & 1 \\
\hline \multicolumn{6}{|l|}{ Notes: } \\
\hline
\end{tabular}

Descriptive statistics of the variables are shown in table 1 . Table 2 shows pairwise correlations between the variables. We can see that there are no serious multicollinearity concerns between reg and corruption. This is partly because we use data on the performance of the three-digit manufacturing sectors such as dairy products, vegetable oils and fats, bidi, wooden furniture, fertilizers and pesticides, aluminum, and agricultural machinery. It is therefore unlikely that the regulation of each three-digit industry is highly correlated with the extent of corruption at the state level.

Table 2: Simple Correlations among Variables

\begin{tabular}{|c|rrr|c|}
\hline & reg & corruption $\begin{array}{c}\text { gross value } \\
\text { added per } \\
\text { worker }\end{array}$ & $\begin{array}{c}\text { capital-labor total factor } \\
\text { ratio } \\
\text { productivity }\end{array}$ \\
\hline $\begin{array}{c}\text { reg } \\
\text { corruption }\end{array}$ & -0.050 & 1 & & \\
$\begin{array}{c}\text { gross value added per } \\
\text { worker }\end{array}$ & -0.037 & 0.014 & 1 & 1 \\
$\begin{array}{c}\text { capital-labor ratio } \\
\text { total factor productivity }\end{array}$ & -0.047 & 0.022 & 0.454 & 0.122 \\
\hline
\end{tabular}




\section{Underreporting problem and construction of a corruption variable}

The variable used to capture the extent of corruption is the number of cases registered under the Prevention of Corruption Act 1988 and related penal codes, as made available in the annual publication Crime in India compiled by the Government of India’s Ministry of Home Affairs.

Official data on corruption is generally aggregated from registered corruption cases. For various reasons, however, many corruption cases are not reported to any relevant authority (e.g., police or anti-corruption bureau). In some cases, both public officials and bribers obtain benefits, damaging only public interests, and thus neither side would have an incentive to report. In other cases, public officials demand payment for the services that they are obliged to provide, but victims do not report the case because they are afraid of nonfulfillment of the service or even possible revenge by public officials. Thus, we expect that the number of cases registered under the Prevention of Corruption Act is far short of the actual number.

To correct this underreporting problem, we adopt a method similar to the one advocated by Soares (2004). Soares tackles the underreporting problem of crimes, including corruption as a subcategory. Reporting rates of crimes are regressed on relevant economic and social variables, and the estimated results are applied to official crime data in order to obtain predicted true crime rates in a cross-national context. Soares has performed this estimation using the ICVS, a comprehensive 
international survey of crime victims covering more than 300,000 citizens in 78 countries from its inception up to the fifth round of the survey, conducted in 2004-2005. Soares (2004) used the dataset collected up to the third round (1996-1997). In our study, it would be preferable to use Indian domestic data on the crime reporting rate and apply the method of Soares (2004) to estimate the predicted true crime incidence in each Indian state, but we are not aware of such a dataset. We will therefore first estimate the crime reporting rate using ICVS data and then apply the estimation results to obtain the predicted true state crime incidence in the various Indian states.

More concretely, we estimate the following simple equation:

$$
R R_{i t}=c_{i j}+b_{1 j} G D P_{i t}+b_{2 j} D D_{i}+e_{i j t},
$$

where $R R_{i t}$ is the reporting rate of corruption in country $i$ in year $t, G D P_{i t}$ is GDP per capita of country $i$ in year $t$ expressed in constant 2000 US dollars as obtained from World Development Indicators; $D D_{i}$ is a developing country dummy variable for country i. Although Soares (2004) suggests a more complete model that includes urbanization, education, and inequality as explanatory variables, the problem of multicollinearity among the explanatory variables led him to the estimation of a simpler model such as the one in our paper. We follow Soares' estimation model in this article.

We aggregate the reporting rates for each country from more than 180,000 individual data 
collected up to the fourth round of the ICVS (2002). We then run a simple OLS regression on the pooled dataset of 66 countries collected over 14 years to obtain the following results:

$$
\begin{array}{r}
R R_{i t}=0.018745+0.00000229 G D P_{i t}+0.0210076 D D_{i}, \\
(3.72)^{* * *} \quad(2.30)^{* *} \quad(2.18)^{* *}
\end{array}
$$

No. of observations $=75, \quad \mathrm{R}^{2}=0.1403, \quad \mathrm{~F}(2,72)=4.47(\mathrm{p}$-value $=0.0147)$.

Here, the numbers in parentheses are t-values, and ${ }^{* * *}$ and ${ }^{* *}$ indicate one per cent and five per cent significance, respectively. GDP per capita and the developing country dummy are both statistically significant at the five per cent level. For instance, according to the result, the reporting rate of corruption in a developing country with per capita GDP equal to 5000 constant 2000 US dollars in a year is predicted to be $0.018745+0.00000229 * 5000+0.0210076=0.0512026$.

We apply these regression results to Indian states in each year to obtain a prediction of the reporting rate of corruption, where $D D$ is set to one for all states. The mean of the predicted reporting rates across Indian states and sample years is 0.0400789 , which indicates that the true incidence of corruption is, on average, about 25 times higher than the official reported cases. We divide the official data on the incidence of corruption by predicted reporting rates to obtain the predicted true corruption incidence. We normalize the number by dividing it by population in 
thousands for each state. We then take the average value of this variable over the current and previous periods. We use the variable constructed in this way as our explanatory variable to capture the extent of corruption. This variable is hereafter referred to as corruption. Descriptive statistics of corruption are given in table 3.

Table 3. Descriptive Statistics of corruption

\begin{tabular}{|l|c|c|c|c|c|c|}
\hline & No. of observations & Mean & Median & S.D. & Min & Max \\
\hline corruption & 135 & 0.0762 & 0.0695 & 0.0586 & 0 & 0.448 \\
\hline
\end{tabular}

Note: corruption is the average value of predicted true incidence of corruption-related cases per population over the current and previous periods.

\section{Estimation Results}

We run instrumental variable estimation with industry, state, and year fixed effects. Table 4 shows the first-stage estimation results for three dependent variables. F-tests reject the null hypotheses that all the coefficients are zero, and the values of R-squared are reasonable. An underidentification test is conducted with the test statistics, which are chi-squared distributed with degrees of freedom equal to one under the null hypothesis that corruption is underidentified by conviction rates and conviction rate times regulation dummy variable. The test statistic is high with p-values close to zero, indicating a rejection of the null hypothesis. The test statistic for the weak identification test (Wald F-statistic based on Kleibergen and Paap 2006) has values that are far greater than the critical values proposed by Stock and Yogo (2001), indicating that it is unlikely that the conviction rate and conviction rate times regulation dummy variable are weak instruments. These results indicate that first-stage 
estimation has been reasonably performed. The coefficient of conviction and that of reg*conviction

are mostly significant at the conventional significance level. Especially, the result shows that as conviction rate increases, corruption decreases, which is consistent with the expectation that since a high conviction rate raises the possibility of being caught and punished, public officials would refrain from corrupt behavior.

Table 4. Instrumental Variable Estimation Results: First Stage

\begin{tabular}{|c|c|c|c|c|c|c|c|c|c|}
\hline $\begin{array}{l}\text { (Dependent variable in Second Stage) } \\
\text { Dependent variable: corruption }\end{array}$ & \multicolumn{3}{|c|}{$\begin{array}{c}(1) \\
\left(\begin{array}{c}\text { (log gross value added } \\
\text { per worker) }\end{array}\right.\end{array}$} & \multicolumn{3}{|c|}{$\begin{array}{c}(2) \\
\text { (log total factor } \\
\text { productivity) }\end{array}$} & \multicolumn{3}{|c|}{$\begin{array}{c}(3) \\
\text { (log capital labor ratio) }\end{array}$} \\
\hline conviction $(-1)$ & -0.1499 & $(0.0048)$ & **** & -0.1497 & $(0.0048)$ & $* * *$ & -0.1505 & $(0.0048)$ & $* * *$ \\
\hline reg & -0.0063 & $(0.0010)$ & $* * *$ & -0.0063 & $(0.0010)$ & $* * *$ & -0.0063 & $(0.0010)$ & $* * *$ \\
\hline reg*conviction $(-1)$ & 0.0177 & $(0.0073)$ & ** & 0.0178 & $(0.0073)$ & ** & 0.0179 & $(0.0072)$ & ** \\
\hline$t$ & 0.0136 & $(0.0007)$ & $* * *$ & 0.0136 & $(0.0007)$ & $* * *$ & 0.0133 & $(0.0007)$ & $* * *$ \\
\hline $\mathrm{R}^{2}$ & 0.9126 & & & 0.9127 & & & 0.9138 & & \\
\hline F-Statistics ( $p$-value) & 1842.44 & (0) & & 2878.04 & (0) & & 2923.96 & (0) & \\
\hline \multicolumn{10}{|l|}{ Dependent variable: reg*corruption } \\
\hline conviction $(-1)$ & -0.0102 & $(0.0057)$ & * & -0.0100 & $(0.0057)$ & * & -0.0087 & $(0.0057)$ & \\
\hline reg & 0.0872 & $(0.0016)$ & **** & 0.0872 & $(0.0016)$ & **** & 0.0879 & $(0.0016)$ & *** \\
\hline reg*conviction $(-1)$ & -0.0682 & $(0.0146)$ & $* * *$ & -0.0682 & $(0.0146)$ & $* * *$ & -0.0925 & $(0.0143)$ & \\
\hline$t$ & 0.0055 & $(0.0009)$ & $* * *$ & 0.0055 & $(0.0009)$ & $* * *$ & 0.0059 & $(0.0009)$ & $* * *$ \\
\hline $\mathrm{R}^{2}$ & 0.698 & & & 0.698 & & & 0.6957 & & \\
\hline F-Statistics ( $p$-value) & 255.14 & (0) & & 254.87 & (0) & & 257.69 & (0) & \\
\hline \multicolumn{10}{|l|}{ Underidentification test } \\
\hline \multicolumn{10}{|l|}{ Weak identification test } \\
\hline $\begin{array}{l}\text { rk Wald F-statistic } \\
\text { Stock-Yogo weak ID test critical value: } \\
10 \% \text { maximal IV size }=7.03\end{array}$ & \multicolumn{3}{|l|}{11.87} & \multicolumn{3}{|c|}{11.87} & \multicolumn{3}{|l|}{13.43} \\
\hline Number of observations & \multicolumn{3}{|l|}{13615} & \multicolumn{3}{|c|}{13609} & \multicolumn{3}{|l|}{13945} \\
\hline \multicolumn{10}{|c|}{$\begin{array}{l}\text { Notes: } * * * \text { indicates } 1 \% \text { significant, } * * 5 \% \text {, and } * 10 \% \text {. Numbers in parentheses are heteroskedasiticiy robust standard errors, unless otherwise indicated. } \\
\text { gross value added per worker: real gross value added divided by the number of workers (in Rs lakhs). } \\
\text { capital-labor ratio: real capital stock divided by the number of workers (in Rs lakhs). } \\
\text { total factor productivity: TFP is obtained from estimated production function based on Levinsohn and Petrin's method. } \\
\text { reg: regulation dummy that is set to } 1 \text { if the } 3 \text {-digit manufacturing sector is regulated and to } 0 \text { otherwise. } \\
\text { corruption: corruption is the average over the last two years of predicted true incidence of corruption-related cases per population. } \\
\text { t: time trend variable. }\end{array}$} \\
\hline
\end{tabular}

The results of instrumental variable two-stage least squares estimation for log gross value added per worker are given in table 5. Industry, state and year fixed effects are included in all columns (1)-(4). Standard errors are heteroskedasticity-robust in column (2), both heteroskedasticity- and 
autocorrelation-robust in column (3), and cluster-robust at state-industry level in column (4). F tests

reject the null hypotheses that all the coefficients are zero, and the values of $\mathrm{R}^{2}$ are also reasonable.

The estimation results show that the coefficient of corruption is negative at one per cent significance

level for all specifications across columns (1)-(4), and the coefficient of regulation is also negative mostly at five per cent significance level. These results are consistent with the previous literature that shows the detrimental effects of corruption and regulation.

Table 5. Instrumental Variable Estimation Results: Second Stage (log gross value added per worker)

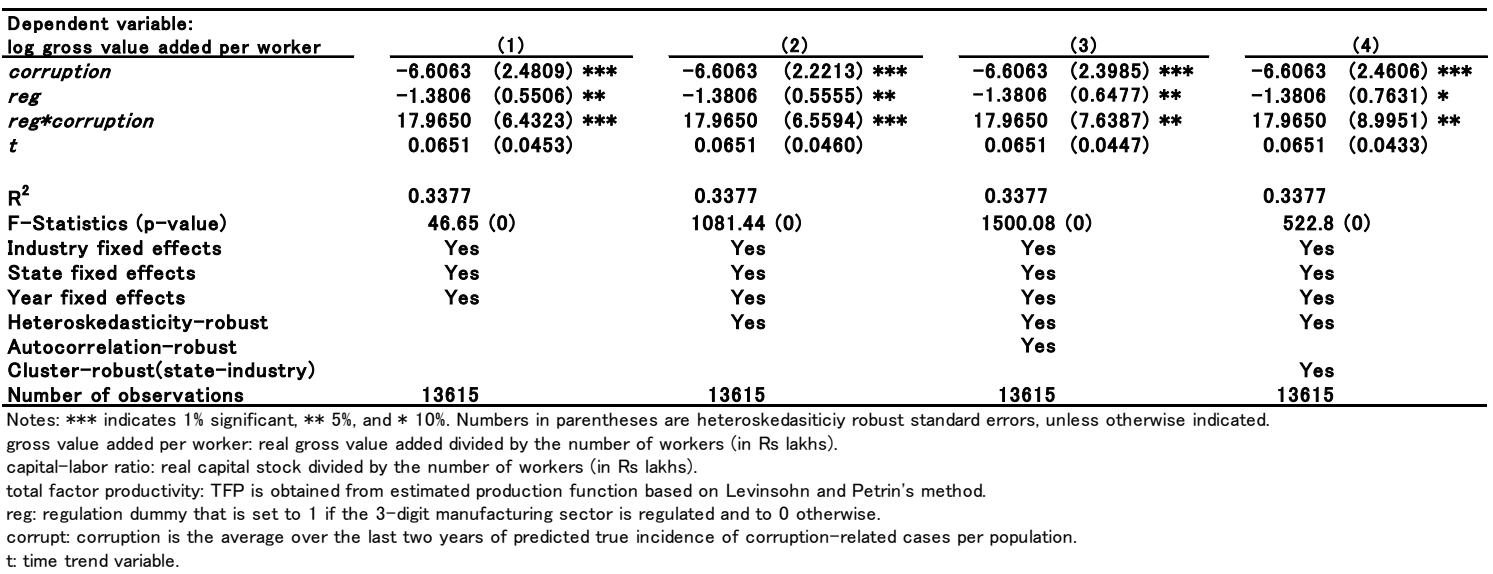

Our main interest in this study is the interaction term. Its coefficient is positive at one per cent

significance level in columns (1) and (2), and at five per cent significance level in columns (3) and (4). These results imply that in regulated manufacturing industries, corruption of public officials offsets the negative effect of regulation, and even enhances the gross value added of the manufacturing sector. This result implies that there is a "greasing the wheels" effect. 
Next we interpret our estimation results. If corruption increases marginally, gross value added per worker changes by $-6.6+17.97 *$ reg. Hence, if an industry is not regulated (i.e., reg=0), the increase in corruption reduces the gross value added per worker, while if the industry is regulated (i.e., reg=1), the increase in corruption raises it. To compare regulated and deregulated industries, we subtract the right-hand side of the estimated equation with $r e g=0$ from that with $r e g=1$, yielding $-1.38+17.97 *$ corruption. Hence, the shift from unregulated industry to regulated industry leads to a reduction in gross value added per worker if corruption $<1.38 / 17.97=0.0768$, while there is a rise in gross value added per worker if corruption $>0.0768$. Since the median of corruption is 0.0695 (Table 3), in more than half of our sample cases, regulation of a manufacturing industry actually lowers its gross value added per worker.

Since we have found some interesting effects on gross value added per worker, we will examine the channels through which these effects work, whether total factor productivity or capital labor ratio or both. Table 6 presents the estimation results for log total factor productivity. The results are very similar to those in table 5. We find negative coefficients on corruption and regulation and a positive coefficient on their interaction term. They are also significant across many specifications, as seen in table 6. Though the interaction term is not significant in column (4), we more or less confirmed a "greasing the wheels" effect of corruption with respect to TFP. A similar calculation shows that the marginal increase in corruption induces a change in TFP by $-5.6+11.1994$ reg. The change is 
negative if the industry is unregulated (reg=0), but positive if the industry is regulated (reg=1). The

shift from unregulated industry to regulated industry leads to a reduction in TFP if corruption $<0.0754$ but an increase in TFP if corruption $>0.0754$. This indicates that in more than half of our cases regulation reduces the TFP of the industry.

Table 6. Instrumental Variable Estimation Results: Second Stage (log total factor productivity)

\begin{tabular}{|c|c|c|c|c|c|c|c|c|}
\hline $\begin{array}{l}\text { Dependent variable: } \\
\text { log total factor productivity }\end{array}$ & \multicolumn{2}{|r|}{$(1)$} & \multicolumn{2}{|r|}{ (2) } & \multicolumn{2}{|r|}{ (3) } & \multicolumn{2}{|r|}{$(4)$} \\
\hline & -5.5896 & $(2.1099) * * *$ & -5.5896 & $(1.8667) * * *$ & -5.5896 & $(1.9982) * * *$ & -5.5896 & $(2.0294) * * *$ \\
\hline reg & -0.8453 & $(0.4685) *$ & -0.8453 & $(0.4663) *$ & -0.8453 & $(0.5334)$ & -0.8453 & $(0.6040)$ \\
\hline reg*corruption & 11.1994 & $(5.4736) * *$ & 11.1994 & $(5.4947) * *$ & 11.1994 & $(6.2832) *$ & 11.1994 & $(7.1244)$ \\
\hline$t$ & 0.0686 & $(0.0386) *$ & 0.0686 & $(0.0396) *$ & 0.0686 & $(0.0390) *$ & 0.0686 & $(0.0379) *$ \\
\hline $\mathrm{R}^{2}$ & 0.1719 & & 0.1719 & & 0.1719 & & 0.1719 & \\
\hline F-Statistics ( $p$-value) & 21.67 & (0) & 1222.14 & (0) & 409.36 & (0) & 986.02 & (0) \\
\hline Industry fixed effects & Yes & & Yes & & Yes & & Yes & \\
\hline State fixed effects & Yes & & Yes & & Yes & & Yes & \\
\hline Year fixed effects & Yes & & Yes & & Yes & & Yes & \\
\hline Heteroskedasticity-robust & & & Yes & & Yes & & Yes & \\
\hline Autocorrelation-robust & & & & & & & & \\
\hline Cluster-robust(state-industry) & & & & & & & Yes & \\
\hline Number of observations & 13609 & & 13609 & & 13609 & & 13609 & \\
\hline
\end{tabular}

Finally, table 7 presents the estimation results for log capital labor ratio. Note that the coefficient of corruption is negative but no longer significant, indicating corruption itself does not affect capital labor ratio significantly. The coefficient of regulation is negative and significant in columns (1)-(3). In other words, under regulation, firm investment in physical capital relative to labor is lowered, which is in agreement with the theory that cumbersome regulation reduces incentives for corporate managers to invest in physical capital. The coefficient of the interaction term is positive and significant in all columns (1)-(4). Although its significance levels are lower than in the case of gross 
value added per worker, corruption has a "greasing the wheels" effect with respect to capital labor ratio, in spite of insignificant effects of corruption itself on capital labor ratio. Our estimation results indicate that since the marginal effect of the increase in corruption is $-1.47+15.576^{*}$ reg, as corruption level rises, capital labor ratio falls for unregulated industries and rises for regulated industries. In the shift from being unregulated to being regulated, capital labor ratio rises if corruption $>1.24 / 15.58=0.0796$ but falls if corruption $<0.0796$. Again, in more than half of our sample cases, the shift to regulation reduces capital labor ratio.

Table 7. Instrumental Variable Estimation Results: Second Stage (log capital labor ratio)

\begin{tabular}{|c|c|c|c|c|c|c|c|c|}
\hline \multirow{2}{*}{$\begin{array}{l}\text { Dependent variable: } \\
\text { log capital labor ratio } \\
\text { corruption }\end{array}$} & \multicolumn{2}{|r|}{ (1) } & \multicolumn{2}{|r|}{ (2) } & \multicolumn{2}{|r|}{ (3) } & \multicolumn{2}{|c|}{ (4) } \\
\hline & -1.4708 & $(2.6871)$ & -1.4708 & $(2.4829)$ & -1.4708 & $(2.7185)$ & -1.4708 & $(2.6694)$ \\
\hline reg & -1.2371 & $(0.5791) * *$ & -1.2371 & $(0.5856) * *$ & -1.2371 & $(0.6860) *$ & -1.2371 & \\
\hline reg*corruption & 15.5762 & $(6.7220) * *$ & 15.5762 & $(6.8315) * *$ & 15.5762 & $(7.9862) *$ & 15.5762 & $(9.2350) *$ \\
\hline$t$ & -0.0330 & $(0.0503)$ & -0.0330 & $(0.0512)$ & -0.0330 & $(0.0505)$ & -0.0330 & $(0.0481)$ \\
\hline $\mathrm{R}^{2}$ & 0.4613 & & 0.4613 & & 0.4613 & & 0.4613 & \\
\hline F-Statistics ( $p$-value) & 64.78 & (0) & 423.96 & (0) & 268.95 & (0) & 1209.36 & (0) \\
\hline Industry fixed effects & Yes & & Yes & & Yes & & Yes & \\
\hline State fixed effects & Yes & & Yes & & Yes & & Yes & \\
\hline Year fixed effects & Yes & & Yes & & Yes & & Yes & \\
\hline Heteroskedasticity-robust & & & Yes & & Yes & & Yes & \\
\hline Autocorrelation-robust & & & & & Yes & & & \\
\hline Cluster-robust(state-industry) & & & & & & & Yes & \\
\hline Number of observations & 13945 & & 13945 & & 13945 & & 13945 & \\
\hline
\end{tabular}

Notes: *** indicates $1 \%$ significant, ** 5\%, and * 10\%. Numbers in parentheses are heteroskedasiticiy robust standard errors, unless otherwise indicated. gross value added per worker: real gross value added divided by the number of workers (in Rs lakhs).

capital-labor ratio: real capital stock divided by the number of workers (in Rs lakhs).

total factor productivity. TFP is obtained from estimated production function based on Levinsohn and Petrin's method

reg: regulation dummy that is set to 1 if the 3 -digit manufacturing sector is regulated and to 0 otherwise.

corrupt: corruption is the average over the last two years of predicted true incidence of corruption-related cases per population.

t: time trend variable.

In summary, our estimation results show a "greasing the wheels" effect with respect to gross

value added of Indian manufacturing sectors. This effect was found to work through both TFP and

capital labor ratio: Regulation tends to reduce both TFP and capital labor ratio, and corruption offsets 
the negative effects of regulation.

Our estimation results are consistent with the findings by Sinha (2005). Almost all industrialists in Gujarat told her that the extent of corruption is very high (p.228). She quoted a senior official of SIDC (State Industrial Development Corporation) as saying, "You know something; there are two kinds of bureaucrats. One who takes a bribe and does your work and another who takes your bribe and does not do the work. There is no third type. Now tell me, what kind do you want?” (p.229) In contrast, West Bengal is widely considered to be a low-corruption state. Sinha (2005) quoted a manager of an extremely reputable company in West Bengal saying, "I wish there was more corruption in West Bengal. Then things might move and I would know that I could do something to speed things up. Currently, nothing moves; the government officers are usually honest and morally superior, but they refuse to help you.” ${ }^{8}$ This anecdote from Sinha (2005) is consistent with the "greases the wheels" view. Gujarati bureaucrats work very hard to attract investments into the state, but demand around five per cent to eight per cent of the total project as bribes (Sinha 2005 p.229). This observation seems to imply that the bribery offers a strong motivation for Gujarati bureaucrats to work very hard, leading to superior economic performance of the manufacturing sectors in Gujarat.

The policy implications for present India are as follows. Since the 1980s and early 1990s, many manufacturing industries have become deregulated (in our model, the shift from reg=1 to reg=0 
occurred). Our estimation results show that gross value added per worker, our main performance variable, is expected to increase only in states with sufficiently low corruption. Although corruption may have a "greasing the wheels" effect under regulation, it has only detrimental effects on economic performance in unregulated industries. Therefore, if political leaders of state governments truly intend to promote industrialization, they must combat corruption inside their state governments. If successful, the reduction in corruption would enhance both TFP and capital labor ratio, leading to higher gross value added per worker.

\section{Conclusion}

In this article, we show that the combination of regulation and corruption has positive effects on gross value added per worker, TFP, and capital labor ratio. These results seem to imply that corruption may exert a "greasing the wheels" effect on the dysfunctional Indian bureaucracy. Sinha (2005) states, “...in heavily regulated systems such as India, bribes may provide institutional and noninstitutional substitutes to facilitate investment, an activity discouraged by formal rules” (p.231). When interpreting our estimation results from the opposite perspective, we can conclude that once a manufacturing subsector is deregulated, corruption no longer has a positive effect. Hence, in the era of economic liberalization, especially after 1991, Indian states with lower corruption may be able to enhance the economic performance of manufacturing sector. Thus, it is important for each state 
government to combat corruption to promote industrial development.

\section{References}

Abramo, W.C., 2005. How far do perceptions go? Working paper. Transparency Brazil.

Aidt, T.S., 2003. Economic analysis of corruption: A survey. Economic Journal, 113, 632-652.

Aghion, P., Algan, Y., Cahuc, P., Shleifer, A., 2010. Regulation and distrust. Quarterly Journal of Economics, 125(3),

1015-1049.

Aghion, P., Burgess, R., Redding, S.J., Zilibotti, F., 2008. The unequal effects of liberalization: evidence from dismantling the License Raj in India. American Economic Review, 98, 1397-1412.

Alesina, A., Nicoletti, G., Ardagna, S., Schiantarelli, F., 2005. Regulation and investment. Journal of the European Economic Association, 3 (4), 791-825.

Andvig, J.C., 2005.. A house of straw, sticks or bricks? Some notes on corruption empirics. Paper presented at the IV Global Forum on Fighting Corruption and Safeguarding Integrity, Session Measuring Integrity, June 7, 2005.

Bajpai, N., Sachs, J.D., 1999. The progress of policy reform and variations in performance at the sub-national level in India. Development Discussion Paper No.730. Harvard Institute for International Development.

Barseghyan, L., 2008. Entry costs and cross-country differences in productivity and output. Journal of Economic Growth, 13, 145-167.

Basanini, A., Ernst, E., 2002. Labour market institutions, product market regulation, and innovation: Cross country 
evidence.” Economics Department Working Papers No.316, OECD.

Bertrand, M., Djankov, S., Hanna, R., Mullainathan, S. 2007. Obtaining a driver’s license in India: An experimental approach to studying corruption. Quarterly Journal of Economics, 122(4), 1639-1676.

Bhagwati, J., 1993. India in Transition: Freeing the Economy. New York: Oxford University Press.

Brunetti, A., Kisunko, G., Weder, B., 1998. Credibility of rules and economic growth: evidence from a worldwide private sector survey. World Bank Economic Review, 12, 353-84.

Campos, J.E., Lien, D., Pradhan, S., 1999. The impact of corruption on investments: Predictability matters. World Development, 27, 1059-67.

Chibber, P., Nooruddin, I., 2004. Do party systems count? : The number of parties and government performance in the Indian states. Comparative Political Studies, 37(2), 152-187.

Desai, M., Gompers, P., and Lerner, J., 2003. Institutions, capital constraints and entrepreneurial firm dynamics: Evidence form Europe. Harvard NOM Research Paper No.03-59, Harvard Business School.

Djankov, S., McLiesh, C., Ramalho, R.M., 2006. Regulation and growth. Economics Letters, 92, 395-401.

Dreher, A., Gassebner, M., 2013. Greasing the wheels of entrepreneurship? The impact of regulations and corruption on firm entry. Public Choice, 155, 413-432.

Dreher, A., Herzfeld, T. 2005. The Economic costs of corruption: A survey and new evidence. Mimeo, ETH Zurich.

Gardiner, J., 2002. Defining corruption. In M. Johnston and M. Heidenheimer, eds., Political Corruption: Concepts and Contexts. 3rd ed. New Brunswick, New Jersey: Transaction Publishers. 
Glaeser, E.D., Saks, R.E., 2006. Corruption in America. Journal of Public Economics, 90, 1053-72.

Goel, R.K., Nelson, M.A., 1998. Corruption and government size: A disaggregated analysis. Public Choice, 97, $107-120$

Goel, R.K., Rich, D.P., 1989. On the economic incentives for taking bribes. Public Choice, 61, 269-75.

Gyimah-Brempong, K., 2002. Corruption, economic growth, and income inequality in Africa, Economics of Governance, 3, 183-209.

Hall, R.E., Jones, C.I., 1999. Why do some countries produce so much more output per worker than others? Quarterly Journal of Economics, 114, 83-116.

Harriss, J., 2003. Do political regimes matter? : Poverty reduction and regime differences across India. In: P.P.

Houtzager and M. Moore, eds. Changing paths : international development and the new politics of inclusion.

Ann Arbor: University of Michigan Press, 204-232.

Huntington, S., 1968. Political Order in Changing Societies. Yale University Press, New Haven.

Iarrosi, G., 2009. The Investment Climate in 16 Indian States. Policy Research Working Paper No. 4817, The World

Bank.

Jain, A.K., 2001. Corruption: A review. Journal of Economic Surveys, 15(1), 71-121.

Jenkins, R., 2004. Introduction. In: R. Jenkins, ed., Regional reflections: Comparing politics across India's states.

New Delhi: Oxford University Press, 1-25.

Kaufmann, D., 1997. Corruption: The facts. Foreign Policy, Summer 1997, 114-131. 
Kaufmann, D., Kraay, A., Zoido-Lobaton, P., 1999. Governance matters. World Bank Policy Research Working Paper No. 2196. Washington, DC

Kaufmann, D., Wei, S.-J., 2000. Does 'grease money’ speed up the wheels of commerce? IMF Working Paper 00/64.

Kennedy, L., Robin, K., Zamuner, D., 2013. Comparing state-level policy responses to economic reforms in India: A subnational political economy perspective. Économie Politique de l’Asie (1).

Klapper, L., Laeven, L., Rajan, R., 2006. Entry regulation as a barrier to entrepreneurship, Journal of Financial Economics, 82, 591-629.

Kohli, A., 2006. Politics of economic growth in India, 1980-2005. Part II: The 1990s and beyond. Economic and Political Weekly, April 8, 1361-1370.

Lambsdorff, J.G., 2006. Causes and consequences of corruption: What do we know from a cross-section of countries? In: S. Rose-Ackerman, ed., International Handbook on the Economics of Corruption, pp. 3-51. Edward Elgar Publishing Limited.

Levinsohn, J., Petrin, A., 2003. Estimating production functions using inputs to control for unobsevables, Review of Economic Studies, 70, 317-342.

Leys, C., 1970. What is the problem about corruption? In Political Corruption: Readings in Comparative Analysis, Holt Renehart, New York, pp. 31-37.

Loayza, N.V., Oviedo, A.M., Serven, L., 2005a. The Impact of regulation on growth and infromality: cross-country evidence. Policy Research Working Paper Series No.3423, the World Bank. 
Loayza, N.V., Oviedo, A.M., Serven, L., 2005b. Regulation and macroeconomic performance. Policy Research Working Paper Series No.3469, the World Bank.

Lui, F., 1985. An equilibrium queuing model of corruption, Journal of Political Economy, 93, 760-81.

Marenin, O., 1997. Victimization surveys and the accuracy and reliability of official crime data in developing countries. Journal of Criminal Justice, 25(6), 463-475.

Mauro, P., 1995. Corruption and growth, Quarterly Journal of Economics, 110, 681-712.

Mauro, P., 1997. The effects of corruption on growth, investment, and government expenditure: A cross-country analysis. In: Corruption and the Global Economy, Institute for International Economics, Washington DC, pp.83-107.

Meon, P.-G., Sekkat, K., 2005. Does corruption grease or sand the wheels of growth. Public Choice, 122, 69-97.

Meon, P.-G., Weill, L., 2009. Is corruption an efficient grease? World Development, 38(3), 244-259.

Mocan, N., 2004. What determines corruption? International evidence from micro data. NBER Working Paper No.

10460.

Nicoletti, G, Scarpetta, S. 2003. Regulation, productivity, and growth: OECD evidence. Economic Policy, 18(36), 11-72.

Olken, B.A., 2009. Corruption perceptions vs. corruption reality. Journal of Public Economics, 98(7-8), 950-964.

Philip, M., 1997. Defining political corruption. Political Studies, 45, 436-462. 
Razafindrakoto, M., Routboud, F. 2006. Are international databases on corruption reliable? A comparison of expert

opinion surveys and household surveys in Sub-Saharan Africa. Document de travail DT/2006-17. DIAL, Paris

School of Economics.

Scarpetta, S., Hemmings, P., Tressel, T., Woo, J., 2002. The role of policy and institutions for productivity and firm dynamics: Evidence from micro and industry data. OECD Economics Department Working Paper No. 329.

Shastri, V., 1997. The politics of economic liberalization in India. Comparative South Asia, 6(1), 27-56.

Sheleifer, A., Vishny, W., 1993. Corruption. Quarterly Journal of Economics, 108, 599-617.

Sinha, A., 2005. The Regional Roots of Developmental Politics in India: A Divided Leviathan. Bloomington, IN:

Indiana University Press.

Soares, R.R., 2004. Development, crime, and punishment: accounting for the international differences in crime rates. Journal of Development Economics, 73, 155-184.

Svensson, J., 2005. Eight questions about corruption. Journal of Economic Perspectives, 19, 19-42.

Tanzi, V., Davoodi, H., 1997. Corruption, public investment, and growth. International Monetary Fund Working Paper WP/97/139.

Topalova, P., Khandelwal, A., 2011. Trade liberalization and firm productivity: The case of India. The Review of Economics and Statistics, 93(3), 995-1009.

Wade, R., 1985. The market for public office: Why the Indian state is not better at development. World Development, 13(4), 467-497. 
World Bank, 2008. Doing Business 2008. Oxford University Press.

Wyatt, G., 2002. Corruption, productivity and transition, CERT Discussion Papers No.205, Centre for Economic Reform and Transformation, Heriot Watt University.

1 Jain (2001), Dreher and Herzfeld (2005), and Lambsdorff (2006) provide excellent surveys of the literature. See Aidt (2003) for a survey of the theoretical arguments.

2 See, also, Kaufman and Wei (2000) and Mauro (1995).

3 See Topalova and Khandelwal (2011) for a similar argument that trade liberalization in 1991 was implemented mainly by exogenous forces. They also show that toward the late 1990s trade reforms were becoming a more endogenous variable.

4 Bajpai and Sachs (1999) also show that there is a huge divergence in the policy reforms to attract investment across Indian states. They classified 15 major states into reform-oriented states, intermediate reformers, and lagging reformers and showed that the average growth of per capita gross state domestic product was consistent with their classifications.

5 Furthermore, the performance of three-digit manufacturing level industries is presumed not to affect the conviction rate in corruption-related cases.

6 There are several articles that use corruption-related crime data. For instance, Goel and Rich (1989) use data on the number of public officials convicted of bribery, and Goel and Nelson (1998) use data on the number of public officials convicted of abuse of public office to identify determinants of corruption. Glaeser and Saks (2006) use the number of public officials convicted of a corruption-related crime in each state to find determinants of state corruption level and present evidence of negative effects of corruption on gross state product and median household income. These articles, however, do not carefully address the underreporting problem. By addressing the problem of underreporting, our study complements these studies that use official corruption data.

7 Although some industries were deregulated before 1988, it is difficult to obtain data on corruption before 1988.

8 Sinha (2005) emphasizes that it is important to "make distinctions between types of corruption rather than between corruption and no corruption. Different types of corruption have very different economic effects.” 